\title{
Teaching Difficulties from Interactions and Discourse in a Science Classroom
}

\author{
Awelani V. Mudau \\ Department of Science and Technology Education, \\ University of South Africa, South Africa \\ mudauav@unisa.ac.za
}

\section{Doi:10.5901/jesr.2013.v4n3p113}

\section{Abstract}

The purpose of the study was to evaluate the teaching difficulties of a Physics topic using the classroom practice diagnostic framework (CPDF) with a focus on classroom interactions and discourse. It was a qualitative case study conducted in the Johannesburg district of education in South Africa. Two participants who perceived projectile motion topic to be difficult to teach were interviewed and observed teaching the topic. The results from these participants show that the kinds of interactions and discourses were the following: Type and pattern of discourse which was IRF and Authoritative discourse; Teacher questioning which was for Lesson development and Evaluation; Communicative approach which was Interactive-Authoritative. This kind of interactions and discourses do not advance meaningful learning, misconception dissonance, development of inquiry and problem solving skills which influence student achievement. Suggestions are made on the need to assist in-service teachers on making them conscious of the classroom interactions and discourse they use whilst teaching. It is also suggested that there is a need for further research with more teachers to derive a broad and holistic view of the teaching difficulties emanating from classroom interactions and discourse in the teaching of Physics topics.

Keywords: teaching difficulties, interaction, discourse, projectile motion

\section{Introduction}

The nature of science is the epistemology of science which sees science as a way of knowing tentative knowledge (Akarsu, 2010; Akerson \& Donnelly, 2010; Abd-El-Khalick \& Akerson, 2009; Karakas, 2008; Lederman, 1992). According to Abd-El-Khalick and Akerson (2009), there are various ways of knowing science of which one is through the teaching of science. Consequently, some scholars in science education (Abd-El-Khalick \& Akerson, 2009 and Magnusson et al., 1999) are of the view that science must be taught through inquiry, conceptual change, process, discovery and didactic approaches amongst other approaches. Moreover, the nature of the subject demands that students should learn science to develop inquiry and problem solving skills (Abd-El-Khalick \& Akerson, 2009). Therefore, science teaching is the act and art of teaching students to develop problem solving and inquiry skills. Furthermore, during science teaching, students must make meaningful learning (Leach \& Scott, 2003).

When teachers fail to make the means to achieve the end (Staver, 2007), achievement by students, meaningful learning, development of inquiry and problem solving skills in students (Abd-El-Khalick \& Akerson, 2009) is affected. It follows then that teachers have teaching difficulties as a result. Teaching difficulty is the teachers' classroom practices which do not advance meaningful learning, misconception dissonance, development of inquiry and problem solving skills which influence student achievement.

Furthermore, McDermott (2006) advocates that teachers need to understand the topics they are going to teach at a deeper level. This is so because having taught a particular Physics topic does not necessarily improve the comprehension of that topic. Besides, she indicates that many teachers lack an understanding of very basic concepts in Physics. These assertions are applicable to the South African teacher. Many of the teachers were trained in the former colleges of education and as such have limited content knowledge (Rollnick et al., 2008). They were not taught such that they have a deeper understanding of what they were going to teach.

Teachers usually think that the ability to solve quantitative problems is an indication of good mastery of the subject matter. According to McDermott (2006), the latter is not an indication of strong command of concepts and representational skills. Emphasis should be on reasoning required in the development and application of concepts (McDermott, 2001 and 2006). To avert the challenges in the teaching of Physics, many higher institutions of education (HEI) in South Africa adopted a system wherein pre-service students are taught Physics content in the Physics 
department or by lecturers who are knowledgeable in the Physics content. Hence, the DoE (2006) emphasised the need for teachers to further their studies in Physical Science content. In-service training for CTPD was also instituted to enhance deeper understanding of the science topics. However, the in-service trainings organised for teachers mostly focus on enhancing the content knowledge of the topics to be taught at high school (Mudau, 2013). There is little or no focus in helping the teacher to know how we know and what we know to make science meaningful to students (McDermott, 2006; Mudau, 2013). Moreover, according to Scott (1998), it is not only the activities that Physical Science teachers bring to the classroom to facilitate learning that make students learn but teacher-student talk around the activities and the subject matter also influences learning.

So, Physics can be challenging to teach depending either on how the teacher teaches it, how he was prepared, how he is in-serviced or because of the nature of the content itself. However, Gunstone et al. (2009) indicate that a teacher with a more informed view of learning tends to appreciate the teaching difficulties of a topic and uses the kind of discourse and interactions with students that facilitate meaningful learning. The point is also emphasised by McDermott (2006) when she said that a teacher with a deeper and broader content knowledge and PCK should help students to learn meaningfully. On the other hand, Rollnick et al. (2008:1382) indicate that "it is only when difficulties are known to exist that teaching difficulties may be fully explored and understood." Consequently, this study investigated the teaching difficulties of the topic projectile motion which is perceived to be difficult to teach by some teachers with a focus on interactions and discourse in the classroom. Hence, the investigative question was: What are the teaching difficulties in the teaching of the projectile motion topic with a focus on interactions and discourse?

\section{Literature review}

This section, among others, explores the nature of interactions and discourse in the science classroom as well as the theoretical framework for the study.

\subsection{Interactions and discourse in the science classroom}

Interactions and discourse in the science classroom between the teacher and students is fundamental to learning because it is central to the meaning making process (Mortimer \& Scott, 2003). Meaning making which is a dialogic process (Scott, 1998) occurs in three phases, the social plane where the teacher presents the new content, the internalisation process where the teacher helps students to make sense of the new content and the application of the new content. In a dialogic process the appropriate speech genre needs to be used. Thus, there is a difference between the everyday social language and the social language of school science. So, a science teacher cannot present the content as if it is obvious because students bring ideas of how things are from their ontological perspectives. In the classroom, the teacher explains the concepts differently to the way students may have understood them. The teaching of science can be difficult or effective, stemming from the kind of discourse the teacher uses.

According to Moore (2007), language and discourse are co-dependent. That is, they rely on each other for developing understanding and scientific knowledge. Furthermore, he indicates that language is used to create discourse. On the same note, Moore (2007) also indicates that language can be a gatekeeper or a bridge to a science discourse. This point is also emphasised by Reis and Ng-A-Fook (2010) who posit that language is a limiting factor as it is affected by social contexts. Language does not only affect the discourse in the science classroom but can be a barrier to learning (Case, 2002). Moore (2007) suggests that teachers must have an understanding of the different ways that language shapes discourse. This point is further emphasised by Lee (2005) who indicates that teachers need to have the knowledge of the linguistic abilities of their students to enhance meaningful learning.

\subsection{Theoretical framework}

The classroom practice diagnostic framework (CPDF, figure 1) was used as the lenses to evaluate the teaching difficulties of a Physics topic with a focus on classroom interactions and discourse. 
Figure 1: The Classroom Practice Diagnostic Framework (CPDF)

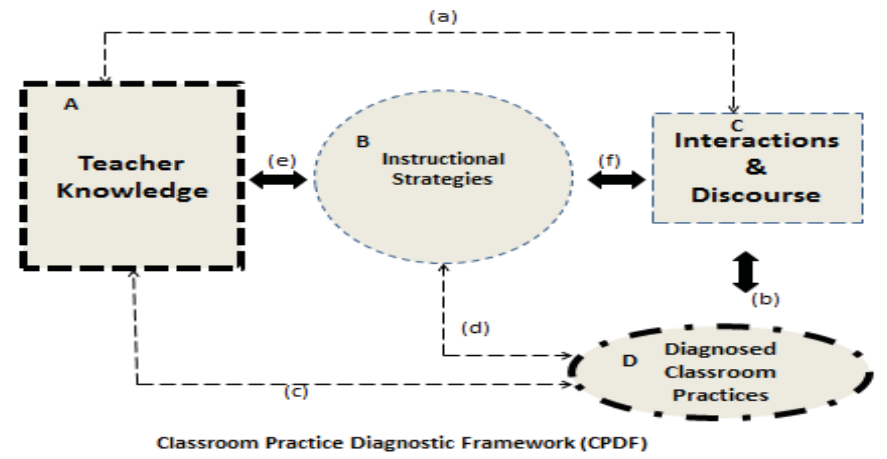

In the classroom interaction and discourse frame, the emphasis was on the types and patterns of discourse, communicative approach and teacher questioning. Types of discourses comprised the authoritative, dialogic and reflective discourses. Some of the actions or activities are spontaneous [this part is accommodated in the link (a) between $\mathrm{A}$ and $\mathrm{C}$ ]. The analysis or diagnosis of teaching difficulties focuses mainly on what happens in frame $\mathrm{C}$, this frame or outcome. The three types of science classroom discourse namely authoritative, dialogic and reflective discourse as expounded by Chin (2006) and Mortimer and Scott (2003) are illustrated in Figure 2.

Figure 2: Science classroom discourse

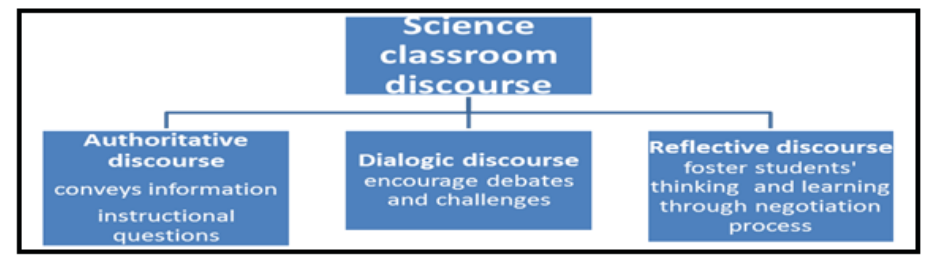

Authoritative discourse is based on one voice, has a fixed intent and outcome and "student utterances are often given in response to teacher questions", whilst dialogic discourse involves many voices and flexible intent and outcome (Chin, 2006:1317). In an authoritative discourse, the teacher conveys information and his utterances are often made up of instructional questions and factual statements, whilst dialogic discourse encourages debates and challenges (Chin, 2006). An alternation between the authoritative and dialogic discourse is desirable for the development of conceptual thinking (Chin, 2006). In reflective discourse, teachers use a process of negotiation of alternative ideas rather than transmission or confrontation to assist students in understanding the concepts (Chin, 2006).

The communicative approach focuses on ways in which the teacher works with the students to address ideas and concepts. There are four classes of communicative approach, namely interactive/authoritative, interactive/dialogic, noninteractive/dialogic and non-interactive/authoritative (Mortimer \& Scott, 2003). According to Chin (2006), in an interactive/authoritative communicative approach, the teacher invites responses but discounts them if they are incorrect as the teacher focuses only on correct answers. The teacher uses a series of questions and answers to reach a specific viewpoint. In contrast, in the interactive/dialogic approach, students' views are taken into account even though they may be alternative to the accepted scientific meaning. Chin (2006) also indicates that the non-interactive/authoritative approach is best represented by the formal lecture, where ideas are presented in a monologue. In a noninteractive/dialogic approach, the teacher does not invite other points of view from the students but in his/her teaching makes statements that also address other points of views in addition to the formal ones (Chin, 2006).

In school science, discourse teacher questioning is prominent (Chin, 2006). For the purposes of this study, two kinds of teacher questions are explained. In traditional lessons, the purpose of questions is for evaluation of what students know and in constructivist based or inquiry-oriented lessons, teachers use questions to help students construct understanding and /or generate meaning. Thus, teachers use questioning "to diagnose, and extend students' ideas and 
scaffold students' thinking" (Chin, 2006: 1319). It follows then that using questions for evaluation is related to an authoritative discourse whilst using questions to generate meaning is related to dialogic and reflective discourse.

The framework was used to diagnose how the teacher supported the meaning-making process (Leach \& Scott, 2003; Mortimer \& Scott, 2003). The focus was on the kind of the communicative approach and discourse the teacher used in the social plane wherein s/he introduced the new subject matter knowledge. This was based on the notion that knowledge is constructed during social interaction (Carr et al., 2004; Lemke, 2001; Kim, 2001; Davydov, 1995). Furthermore, the framework was used as a basis to diagnose how the teacher's classroom interactions and discourse facilitated internalisation of the subject matter knowledge by the students. This was so because according to Vygotsky (1978: 128) "the process of internalisation is where individuals appropriate and become able to use for themselves conceptual tools first encountered on the social plane." So, it is the role of the students to internalise the new knowledge (Leach \& Scott, 2003) and for teachers to support the process. The final phase in the process of meaning-making is the application phase. So, the framework was used as the reference point to diagnose the kinds of interactions and discourse the teacher used to create opportunities for students to answer questions, solve problems and discuss the knowledge (Hausfather, 2001) to reinforce knowledge development. This was so because according to Nola (1997: 59) "only when they can go through the steps of reasoning by themselves and thereby make fully explicit to themselves the reasons for the answer will they have knowledge." The framework was also used to diagnose the kinds of interactions and discourse the teacher used to promote the development of inquiry and problem solving skills.

\section{Methodology}

This qualitative case study research was underpinned by the interpretive research paradigm. Hence, even though the analysis of data and inferences was embedded on what the teachers pronounced in the interviews and observations only, the researcher's experiences of teaching projectile motion, attendance at workshops and cluster meetings and marking National Senior Certificate (NSC) examinations also influenced the resultant interpretations of the analysis and inferences. The research focused on two teachers (cases) from a cluster in the Johannesburg District of Education in South Africa who perceived projectile motion to be difficult to teach. The teachers were interviewed prior to the teaching of the topic and after teaching the topic. They were also observed whilst teaching the topic. Data was presented in tabular format wherein themes which were derived inductively were used to organise data. The tables contained raw data from interviews and observations. Only instances that would relate to interactions and discourse were included. The interpretation of data for meaning was reached by two processes (Hitchcock \& Hughes, 1995) namely: direct interpretations of the individual instances and/or aggregation of instances where in an interpretation was reached after aggregating instances.

\section{Results and discussion}

Table 1 and 2 contain the characteristics of the theme classroom interaction and discourse from the two cases. The focus was on the type and pattern of discourse demonstrated by the teachers, the purpose of their questions as well as the nature of their communicative approach.

\subsection{Case 1 (Mr M)}

Table 1: Classroom interactions and discourse (Mr M)

\begin{tabular}{|c|c|c|}
\hline Theme & Category & Characteristics \\
\hline $\begin{array}{l}\text { Classroom } \\
\text { Interactions and } \\
\text { discourse }\end{array}$ & $\begin{array}{l}\text { Type and } \\
\text { pattern of } \\
\text { discourse }\end{array}$ & $\begin{array}{l}\text { - Mr M when you start to engage learners (students) and say can you write the answer on } \\
\text { the chalkboard it shows that now what they are doing they understand [dialogic] } \\
\text { - (student answered the first question, velocity and acceleration are always in the same } \\
\text { direction) } \\
\text { - First student: it is true (response) } \\
\text { - Mr M: why is it false? (initiation, instructional question) } \\
\text { - First student: because velocity and acceleration are not always in the same direction } \\
\text { - Mr M: is it always the case? (initiation, instructional question) } \\
\text { - First student (does not reply) [no feedback] }\end{array}$ \\
\hline
\end{tabular}




\begin{tabular}{|c|c|c|}
\hline Theme & Category & Characteristics \\
\hline & & $\begin{array}{l}\text { - Second student: it is true and it can also be false...it depends... (response, incorrect) } \\
\text { - Mr M: it cannot be true (response, conveys information, Authoritative) } \\
\text { - Third student: it is true because the object is coming down (response, incorrect) } \\
\text { - Mr M: you don't read and understand the question (authoritative) } \\
\text { - Mr M the answer is false (feedback, factual statement) }\end{array}$ \\
\hline & $\begin{array}{c}\text { Teacher } \\
\text { questioning }\end{array}$ & $\begin{array}{l}\text { - Mr M: which formula can we use? (lesson development, instructional question) } \\
\text { - Mr M: what is the value of a? (lesson development, instructional question) } \\
\text { - Mr M: what is the initial velocity? (lesson development) } \\
\text { - Student: sir I solved the problem using a different formula which means there are other } \\
\text { ways of solving the problem } \\
\text { - Mr M: show us what you did [evaluation] } \\
\text { - Student: solved the problem using the formula } 1 / 2 \text { (vf-vi) } t+\text { vit and got the same answer as } \\
\text { the teacher's (incorrect formula) } \\
\text { - Mr M: where did you get the formula? (evaluation) } \\
\text { - Student: there are many textbooks Sir (response) } \\
\text { - Mr M: in the exam they check the formula and if it is incorrect you will lose marks (conveys } \\
\text { information) } \\
\text { - Student: where will we get the formula?(initiation) } \\
\text { - Mr M: there is a formula sheet...(response) } \\
\text { - Students: but not the area one... } \\
\text { not M: you are taught these formulas in the Mathematics class... (students) but we were } \\
\text { - assumption] } \\
\text { - Student still insist that if his answer is correct the formula is correct) } \\
\text { Mr M: so you are still defending it... if you still have an argument about the equation lets } \\
\text { meet each other later (authoritative discourse) }\end{array}$ \\
\hline & $\begin{array}{l}\text { Communicativ } \\
\text { e approach }\end{array}$ & $\begin{array}{l}\text { - (Mr M solved the problem, interactive but authoritative) } \\
\text { - Mr M: the graph is positive because we are having a straight line [ISMK] } \\
\text { - Student: is it always the case that if the object is moving downwards that direction is } \\
\text { positive? (interaction) } \\
\text { - Mr M: what is the use of making the direction negative if they are in the same direction } \\
\text { (acceleration and velocity) you cannot say the direction towards the ground is negative } \\
\text { (Authoritative, dismissive) }\end{array}$ \\
\hline
\end{tabular}

$\mathrm{Mr} \mathrm{M}$ had begun his lessons by asking questions and students responded to these questions. However, the kind of feedback he provided was one dimensional in the sense that only that which was correct was emphasised and incorrect responses were not interrogated extensively. As such, the provider of the response could not notice why he /she was incorrect. This was necessary because learning occurs through reasoning which enables construction of new meaning (Carr et al., 1994). So if the incorrect response is not engaged with, it creates dissonance in the mind of the student which may hinder the understanding of the new information.

So for instance in one case a judgement was passed that the reason they responded incorrectly was because they did not read questions properly. For example, this happened in the case of a student that responded to the question that acceleration and velocity are always in the same direction. Even though the teacher interacted with the student about the incorrect response, the emphasis was not on assisting the student but on providing the correct answer as a fact. This was not an isolated incident: throughout the lessons the teacher did the same. The kinds of question he employed were instructional and with the intention to convey information, evaluate and develop the lesson as shown in Table 1. As a result, the pattern and kind of discourse in Mr M's classroom was IRF (Carlson, 1990) and authoritative (Chin, 2006). This kind and pattern of discourse does not promote the construction of meaning and debate which is necessary for understanding new concepts.

In another incident a student indicated that although he had used a different formula to solve a problem based on graphs - which the teacher solved using the area formula - he got the same answer as the teacher. The student indicated that he saw the equation from another textbook $\left[1 / 2\left(\mathrm{~V}_{\mathrm{f}}-\mathrm{V}_{\mathrm{i}}\right) \mathrm{t}+\mathrm{v}_{\mathrm{i}} \mathrm{t}\right]$. The formula was incorrect but the teacher did not thoroughly engage the student to explain why his formula was incorrect. Mr M indicated that he would engage with 
the student after class if he still had problems. Other students then indicated that the formula which the teacher used was unfamiliar to them. Mr M indicated that the students were supposed to know that formula as it was taught in the Mathematics class and that it was the area formula. If the teacher had assisted the student who used the incorrect formula in class, it would have also assisted other students who questioned the same approach. The teacher then continued to the next problem without further discussion. It follows then that Mr M's communicative approach was interactive but authoritative (Mortimer \& Scott, 2003). Although Mr M invited responses, he discarded them if they were incorrect and focused only on the correct responses.

When students make meaning from what they are learning it improves the possibilities of performance (Chin, 2006). As the meaning making process occurs in three phases (Mortimer \& Scott, 2003), that is, the social plane, internalisation and application process, Mr M's students were largely exposed to the social plane where aspects like velocity, acceleration and using equations of motion were dealt with. The teacher also used the social language of school science which was appropriate and at the level of the students. However, the internalisation phase was compromised as there were limited opportunities for internalising the new knowledge. This is because Mr M's lessons were epitomised by instructional questions intertwined with the lecture method. For example, when students asked where they would get formulas and gave the incorrect formula, they were told that they would find the formula in the formula sheet. When they further indicated that the formula did not appear on the formula sheet, the teacher replied that he meant those taught in the Mathematics class. Thereafter, he dismissed the incorrect input by the student without further engagement. This was an interacting-authoritative communicative approach (Chin, 2006). This approach is teacher-centred and provides no opportunities for students to interact meaningfully with the subject matter (Chin, 2006; Biggs, 2001).

Furthermore, Mr M's lessons were dominated by the conveying of information to the students and this discourse, intertwined with the type of questions he asked to develop the lesson, was authoritative. For example, when he was solving problems using equations of motion, he would intermittently ask students for input in terms of values for substitution in an equation. This kind of discourse does not foster student thinking (Chin, 2006) which is necessary for the development of problem solving and inquiry skills. Hence, the internalisation and application processes were seriously compromised.

\subsection{Case 2 (Ms R)}

Table 2: Classroom interactions and discourse (Ms Ra)

\begin{tabular}{|c|c|c|}
\hline Theme & Category & Characteristics \\
\hline & $\begin{array}{l}\text { Type and } \\
\text { pattern of } \\
\text { discourse }\end{array}$ & $\begin{array}{l}\text { - Ms R: there are dates given by districts to cover up the syllabus that is why we end up } \\
\text { having intervention classes so that we can be able to cover the syllabus (district shapes the } \\
\text { discourse) } \\
\text { - Ms R: any questions about equations of motion? (Initiation) } \\
\text { - Ms R: if there are not questions we will move to our examples (response, authoritative) } \\
\text { - (Ms Radolo ask students how to solve a problem on projectile motion in two dimension) } \\
\text { - Ms R: are we supposed to use equations of motion? no we use trig ratios (instructional } \\
\text { questions, conveys information) } \\
\text { - Ms R: for a gravitational acceleration you must use } 9.8 \mathrm{~m} / \mathrm{s}^{2} \text { and not } 10 \mathrm{~m} / \mathrm{s}^{2} \text {. (conveys } \\
\text { information) }\end{array}$ \\
\hline $\begin{array}{l}\text { Classroom } \\
\text { Interaction and } \\
\text { discourse }\end{array}$ & $\begin{array}{c}\text { Teacher } \\
\text { questioning }\end{array}$ & $\begin{array}{l}\text { - Ms R: What is a projectile (lesson development, instructional question) } \\
\text { - Ms R: Why does the chalk come down? (lesson development, instructional question) } \\
\text { - Ms R: why are we using the change of displacement as y (lesson development) } \\
\text { - Ms R: Looking at the objects coming down what happened to the velocity? (lesson } \\
\text { - development, instructional question) } \\
\text { - Ms R: we have equations of motion which you did in gradce } 10 \text { the first one is } \mathrm{V}_{\mathrm{f}}=\mathrm{V}_{\mathrm{i}}+\mathrm{a} \Delta \mathrm{t} \\
\text { (Prior knowledge). what are the other ones (evaluation, lesson development) } \\
\text { - Ms R: if you are using equation one }\left(\mathrm{V}_{\mathrm{f}}=\mathrm{V}_{\mathrm{i}}+\mathrm{a} \Delta \mathrm{t} \text { ) what can you change from equation one }\right. \\
\text { if I asked you to calculate time [lesson development, to change a to g] } \\
\left.\text { - Ms R:(from the picture) lets look at equation four ( } \mathrm{S}=\mathrm{V}_{\mathrm{i}} \mathrm{t}+1 / 2 \mathrm{gt} \mathrm{t}^{2}\right) \text { if I have to use it what must } \\
\text { I change? (lesson development-to change } \mathrm{S} \text { to } \Delta y \text {, instructional question) } \\
\text { - Ms R:a man throws a ball at and angle of } 53,1 \text { degrees. Immidiately you see degres what } \\
\text { comes to your mind? (evaluation, lesson development) } \\
\text { - Ms R:are we supposed to use equations of motion? (lesson development, instructional }\end{array}$ \\
\hline
\end{tabular}




\begin{tabular}{|c|c|c|}
\hline Theme & Category & Characteristics \\
\hline & & question) \\
\hline & $\begin{array}{l}\text { Communicati } \\
\text { ve approach }\end{array}$ & $\begin{array}{l}\text { - Ms R: at the highest point the velocity becomes zero. What happens when the object } \\
\text { comes down? (initiation) } \\
\text { - Student: It changes direction. (response) } \\
\text { - Ms R: What else can you say? (initiation) } \\
\text { - Student: (students do not answer but just murmur) } \\
\text { - Ms R: it decreases it becomes a minus (M, interactive, Authoritative) } \\
\text { - Ms R: Any questions? (initiation) } \\
\text { - Student: Why is the value negative? (transposing a value to the other side of the equal } \\
\text { sign) } \\
\text { - Ms R: I thought you did this in Grade } 10 \text { that is why I did not explain, so you want me to } \\
\text { explain? (teacher did not explain but asked for any other question) [interactive but } \\
\text { authoritative] }\end{array}$ \\
\hline
\end{tabular}

During the lesson presentation, Ms R's classroom was characterised by interactions which she initiated herself. For example, when she introduced the lesson she indicated that she would start by making students understand vertical and horizontal motion and ask what projectile motion is. She also conveyed information to students; for example, when a problem on projectile motion in two dimensions was to be solved she asked students if they had to use equations of motion. She would then immediately respond that they had to use trigonometrical ratios. So, she initiated, responded and at the same time conveyed information on the subject matter. According to Carlson (1990), this is an IRF pattern of discourse. The situation where information is conveyed without meaningful engagements does not promote the development of conceptual thinking (Chin, 2006). By not encouraging debate and engagement with students in the learning process, Ms R was operating in an authoritative discourse (Chin, 2006).

Ms R also used questions to develop the lesson and evaluate whether students heard what she said. For example, in one instance when she wanted to show students that symbol $\mathrm{S}$ (displacement) has to be changed to $\Delta \mathrm{Y}$ she simply said "let us look at the equation and what must I change?" This question did not only help develop the lesson but it was also an instructional question. Using questions for developmental purposes of the lesson only and not to diagnose and scaffold students' ideas, deprives them of opportunities to meaningfully engage with the subject matter and construct their own understanding (Chin, 2006).

Ms R's communicative approach was non-interactive and authoritative (Mortimer \& Scott, 2003). This is so because in one instance it was noticed that when solving problems using equations of motion she assumed that students knew how to transpose values to the other side of the equal sign, that is, a negative becoming a positive and vice versa. Even though students brought this to her attention she did not engage them on their challenge but proceeded to the next example whilst only indicating that she thought that they knew this as it is Grade 10 work. This was not an isolated incident. Still, in most cases she asked a question and if students did not respond or responded incorrectly she provided the answer. For example, in one instance she told them that at the highest point the velocity of the object is zero and then asked them what happens to the velocity when it comes down. When students did not respond but murmured amongst themselves she provided an answer. Additionally, Ms R's lessons were largely characterised by the lecture method which, according to Mortimer and Scott (2003), is characteristic of a non-interactive-authoritative approach.

\section{Conclusion}

The type and pattern of discourse of both the teachers was IRF and authoritative discourse. They both asked questions to develop the lesson as well as to evaluate what students have learnt. Mr M's communicative approach was largely interactive-authoritative whilst that of Ms R was non-interactive-authoritative. The kind of interactions and discourse from the two teachers do not advance meaningful learning, achievement by students, development of inquiry and problem solving skills in students. However, the teachers thought that they are doing the proper thing and were surprised why student do not perform and perceived the topic to be difficult to teach. Furthermore, taking into consideration that the DBE $(2010,2011 a)$ asks questions to test for inquiry and problem solving skills, students were at a disadvantage. The research has shown that one of the reasons that students do not perform in the topic may be in the subject at large is the nature of the interaction and discourse employed by the teacher in the classroom when teaching. It is suggested that there is a need for in-service teachers to be assisted on the need to be conscious of the kinds of interactions and discourse they employ in the classroom. For the in-service teachers this could be done through in-service trainings. It is 
also suggested that for the pre-service teachers it could be infused in their training and enhanced during their teaching practice sessions. It is also suggested that there is a need to conduct further research on a large scale so that broad and holistic teaching difficulties emanating from classroom interactions and discourse could be analysed and harnessed.

\section{References}

Abd-El-Khalick, F. and Akerson, V. (2009). The influence of metacognitive training on preservice elementary teachers' conceptions of nature of science. International Journal of Science Education, 31(16), 2161-2184.

Akarsu, B. (2010). The influence of disciplines on the knowledge of science: a study of the nature of science. Bulgarian Journal of Science and Education Policy, 4(1), 99-118.

Akerson, V. and Donnelly, L.A. (2010). Teaching nature of science to K-2 students: What understanding can they claim? International Journal of Science Education, 32(1), 97-124.

Biggs, J. (2001). The reflective institution: assuring and enhancing the quality of teaching and learning. Higher Education, 41, $221-238$.

Carlson, R.E. (1990). Assessing teachers' pedagogical content knowledge: item development issues. Journal of Personnel Evaluation in Education, 4, 157-173

Carr, M., Barker, M., Beverley, B., Biddulph, B., Jones, A., Kirkwood, V., Pearson, J. and Symington, D. (1994). The constructivist paradigm and some implications for science content and pedagogy. In: P. Fensham, R. Gunstone, and R. White. The content of science: a constructivist approach to its teaching and learning. London: Falmer Press, pp. 147-158.

Case, R.E. (2002). The intersection of language, education, and context. Science instruction for ESL students. The Clearing House, 76(2), 71-74.

Chin, C. (2006). Classroom interaction in science: teacher questioning and feedback to students' responses. International Journal of Science Education, 28(11), 1315-1346.

Davydov, V.V. (1995). The influence of L.S. Vygotsky on education theory, research and practice. Educational Researcher, 24(3), $12-21$.

Department of Basic Education. (2010). Road show reports. Pretoria: Department of Basic Education.

Department of Basic Education. (2011a). Report on the National Senior Certificate examination results. Pretoria: Department of Basic Education.

Department of Education. (2006). National policy framework for teacher education and development in South Africa. Pretoria: Department of Education.

Gunstone, R., Mulhall, P. and McKittrick, B. (2009). Physics teachers' perceptions of the difficulty of teaching electricity. Research in Science Education, (39), 515-538.

Hitchcock, G. and Hughes, D. (1995) Research and the teacher: a qualitative introduction to school-based research. London and New York: Routledge.

Karakas, M. (2008). A study of undergraduate students' perceptions about nature of science. Bulgarian Journal of Science and Education Policy, 2(2), 233-249.

Kim, B. (2001). Social constructivism. Emerging perspectives on learning, teaching and technology. [Online] Available: http://www.coe.uga.edu/epltt/socialConstructivism.html [Accessed 10 October 2012].

Leach, J. and Scott, P. (2003). Individual and sociocultural views of learning in science education. Science \& Education, 12(1), $91-113$.

Lederman, N.G (1992). Students' and teachers' conceptions about the nature of science: a review of the research. Journal of Research in Science Teaching, 29, 331-359.

Lee, O. (2005). Science education with English language learners: synthesis and research agenda. Review of Educational Research, 75(4), 491-5301.

Lemke, J.L. (2001). Articulating communities: sociocultural perspectives on science education. Journal of Research in Science Teaching. 38(3), 296-316.

McDermott, L.C. (2001). Oersted medal lecture 2001: "Physics Education Research-The key to student learning". American Journal of Physics, 69 (11), 1127-1137.

McDermott, L.C. (2006). Preparing K-12 teachers in Physics: insights from history, experiences, and research. American Journal of Physics, 74 (9), 758-762.

Moore, F.M. (2007). Language in science education as a gatekeeper to learning, teaching and professional development. Journal of Science Teacher Education, 18(2), 319-343.

Mortimer, E.F. and Scott, P.H. (2003). Meaning making in secondary science classrooms. Maidenhead: Open University Press.

Mudau, A.V. (2013). Evaluating the teaching of projectile motion in the grade 12 classrooms. Unpublished doctoral thesis. Tshwane University of Technology, Pretoria.

Reis, G. and Ng-A-Fook, N. (2010). TEK talk: So what? Language and the decolonisation of narrative gatekeepers of science education curriculum. Cultural Studies of Science Education, 5(4), 1009-1026.

Rollnick, M., Bennett, J., Dharsey, N. and Ndlovu, T. (2008). The place of subject matter knowledge in pedagogical content: a case study of South African teachers teaching the amount of substance and chemical equilibrium. International Journal of Science Education, 30(10), 1365-1387.

Scott, P. (1998). Teacher talk and meaning making in science classrooms: a Vygotskian analysis and review. Studies in ScienceEducation, 32(1), 45-80.

Vygotsky, L.S. (1978). Mind in society: the development of higher psychological processes. Cambridge, MA: Harvard University press. 